\title{
Retraction Note to: Pilot-Scale Demonstration of In Situ Chemical Reduction Technology at a Formerly Used Defense Site
}

\author{
Chunhui Luo • Walter O’Niell • Valentine Nzengung
}

Published online: 14 December 2014

(C) Springer International Publishing Switzerland 2014

This article has been retracted because both Walter O'Niell and Valentine Nzengung have indicated they are not co-authors; they have not been involved in the writing of the article.

In addition the corresponding author Chunhui Luo may have used data without permission of the company that produced the data.

The retraction is done without the consent of the corresponding author Chunhui Luo who has been unavailable for comments.

The online version of the original article can be found at http://dx. doi.org/10.1007/s11270-012-1318-y.

C. Luo $(\bowtie) \cdot$ W. O’Niell $\cdot$ V. Nzengung

PLANTECO Environmental Consultants, LLC,

337 South Milledge Avenue, Athens, GA 30605, USA

e-mail: chunhui.luo@gmail.com

W. O’Niell • V. Nzengung

Department of Geology, University of Georgia,

Athens, GA 30602, USA 